\title{
Optimization of Crude Distillation Unit Case Study of the Port Harcourt Refining Company
}

\author{
Zina Jaja, Jackson G. Akpa, Kenneth K. Dagde \\ Department of Chemical/Petrochemical Engineering, Rivers State University, Nkpolu-Oroworukwo, Port Harcourt, Nigeria \\ Email: zina.jaja@ust.edu.ng
}

How to cite this paper: Jaja, Z., Akpa, J.G. and Dagde, K.K. (2020) Optimization of Crude Distillation Unit Case Study of the Port Harcourt Refining Company. Advances in Chemical Engineering and Science, 10, 123-134.

https://doi.org/10.4236/aces.2020.103009

Received: March 18, 2020

Accepted: May 11, 2020

Published: May 14, 2020

Copyright (๑) 2020 by author(s) and Scientific Research Publishing Inc. This work is licensed under the Creative Commons Attribution International License (CC BY 4.0).

http://creativecommons.org/licenses/by/4.0/

\begin{abstract}
An HYSYS model for the crude distillation unit of the Port Harcourt Refining Company has been developed. The HYSYS model developed includes 3 mixers, 3 heaters, 1 heat exchanger, 1 desalter (3-phase separator), 2-phase separator and the main fractionating column. The raw crude was characterized using Aspen HYSYS version 8.8 and the developed model was simulated with the industrial plant data from the Port Harcourt Refining Company. The HYSYS model gave component mole fractions of 0.2677, 0.1572, 0.2687, 0.0547, 0.2517 for Naphtha, Kerosene, Light Diesel Oil (LDO), Heavy Diesel Oil (HDO) and Atmospheric Residue and when compared to plant mole fractions of $0.2710,0.1560,0.2650,0.0530,0.2550$ gave a maximum deviation of $3.2 \%$. The HYSYS model was also able to predict the temperature and the tray of withdrawal for Naphtha, Kerosene, Light Diesel Oil (LDO), Heavy Diesel Oil (HDO) and Atmospheric Residue as follows: tray $1\left(120^{\circ} \mathrm{C}\right)$, tray 12 $\left(206^{\circ} \mathrm{C}\right)$, tray $25\left(215^{\circ} \mathrm{C}\right)$, tray $35\left(310^{\circ} \mathrm{C}\right)$ and tray $48\left(320^{\circ} \mathrm{C}\right)$ which was also compared with plant data and gave a maximum deviation $23.2 \%$. The HYSYS model was then optimized using Sequential Quadratic Programming (SQP) with the industrial plant data as starting values of operating conditions. The optimization increased the mass flow rate of Naphtha product from $7.512 \mathrm{E}+004 \mathrm{~kg} / \mathrm{hr}$ to $7.656 \mathrm{E}+004 \mathrm{~kg} / \mathrm{hr}$, Kerosene product from $5.183 \mathrm{E}+004$ $\mathrm{kg} / \mathrm{hr}$ to $5.239 \mathrm{E}+004 \mathrm{~kg} / \mathrm{hr}$, Light Diesel Oil (LDO) product from $1.105 \mathrm{E}+005$ $\mathrm{kg} / \mathrm{hr}$ to $1.112 \mathrm{E}+005 \mathrm{~kg} / \mathrm{hr}$, Heavy Diesel Oil (HDO) from $2.969 \mathrm{E}+004 \mathrm{~kg} / \mathrm{hr}$ to $2.977 \mathrm{E}+004 \mathrm{~kg} / \mathrm{hr}$ while the last product being Atm Residue remained at $3.157 \mathrm{E}+005 \mathrm{~kg} / \mathrm{hr}$. The new optimum mole fraction values for the five products were as follows: $0.2713,0.1540,0.2635,0.0528$, and 0.2584 while corresponding optimum temperature values were as follows: $129^{\circ} \mathrm{C}, 221^{\circ} \mathrm{C}, 257^{\circ} \mathrm{C}$, $317^{\circ} \mathrm{C}$ and $327^{\circ} \mathrm{C}$.
\end{abstract}

\section{Keywords}

Simulation, Optimization, Mole Fraction, Temperature, Tray Number, Pressure, 
HYSYS

\section{Introduction}

Refining is the process by which the temperature of a liquid mixture is raised and separated into numerous cuts or fractions through the process of condensation and selective boiling. Each cut usually contains volatility of one or more components as well as other properties. In the processing of raw crude, the temperature of the components is raised inside which is a fired furnace and then transferred into a distillation column. When the feed enters the column, the feed is slightly vaporized. As the liquid flows down the column, the components with low boiling point are separated as it rises from the top part of the tower [1].

As the vapour rises, condensation begins with the liquid sliding down from the top part of the column enriched and the less volatile parts begin to condense [2]. Products leaving at the top part of the column are those with a low boiling point and are found to also have high relative volatility.

Products that usually leave at the down part of the column have a high boiling point and low relative volatility [3]. Chemical reactions are usually not accompanied in this process and it is purely based on physical separation. The down part of the column has the highest temperature and pressure and both properties decrease as you move from bottom to the top of the tower.

The vapour rising from the bottom of the tower and the liquid condensing from the top are in equilibrium with each other. Each component in the mixture has its own concentration in the vapour and liquid phase which provides a base for their separation to be effective [4].

In their work [5], steady state models were developed from the principles of Mass and Energy using the mesh equations for a multicomponent Crude Distillation Column. The equations developed were able to predict the concentrations (mole fraction) and temperature of any component/cut of interest from the mixture on the trays of the tower. The validity of the models was compared with plant data of the crude distillation unit (CDU), from the Port Harcourt Refinery. The model applied to the atmospheric distillation tower gave rise to 48 non-linear algebraic equations for any product cut of interest. These equations developed were then changed into matrix form and solved by Matlab using the method of matrix inversion. The model results of the concentration and temperatures for the five products gave values which were compared accurately with data from the atmospheric distillation tower.

[6] studied the novel approach for refinery crude oil operations under uncertainty. To handle fluctuating product demand and uncertain ship arrival time, deterministic formulation was replaced by chance-constrained programming. The relationship between the probability and reliability of a planned operation 
was also discussed.

[7] studied first principle models of crude oil distillation units that were developed using Aspen plus for purpose of pre-design optimization of flowsheet structure and apparatus design and choice of the optimal variant of distillation to provide the process flexibility with respect to the flowrate of crude oil and oil quality. The developed models consider air temperature and type of crude. Parametrical optimization was performed for each step. The alternative upgrading flowsheets were developed to increase operational effectiveness in a wide range of crude oil flowrates. The optimization criterion was developed to evaluate the relative efficiency of the alternative distillation unit flowsheets.

[8] worked on process of crude oil to get intermediate products which are blended to meet quantity, quality and schedule specification of the final products. Refinery optimization is a complex problem therefore it is broken down into sub-problem which is solved independently. The solution obtained using this approach can be improved by integrating different sub-problem for real time optimization.

Optimization is imminent if the quantity and quality of the products of crude distillation unit that will meet desired specifications is to be achieved. Hence the main purpose of this research is to optimize the performance of a crude distillation unit using Aspen HYSYS version 8.8.

\section{Materials and Methods}

\subsection{Materials}

The software used for the process simulation and optimization was Aspen HYSYS version 8.8. The data used was obtained from the Port Harcourt Refining Company and they include: comprehensive crude compositions, feed operating conditions, process description of the various equipment and utilities.

\subsection{Methods}

The methods used in accomplishing this work are outlined as follows:

1) Characterization of crude data collected using Aspen HYSYS:

Characterization method in HYSYS involves conversion of laboratory analysis of crude oil into a series of discrete hypothetical components. This hypo components provide the basis to predict the remaining thermodynamic and other properties of the crude. HYSYS uses the supplied data known as assay to generate internal true boiling point (TBP), molecular weight, density and viscosity curves referred to as working curves. Figure 1 shows how characterization is done using oil manger tool which is inbuilt into Aspen HYSYS software.

2) Building of crude distillation column model into process simulator:

This involves the construction of the crude model into Aspen HYSYS which is shown in Figure 2.

3) Process optimization: this is carried out to ensure the optimum mole fraction of the simulated model is obtained using the method of sequential quadratic 


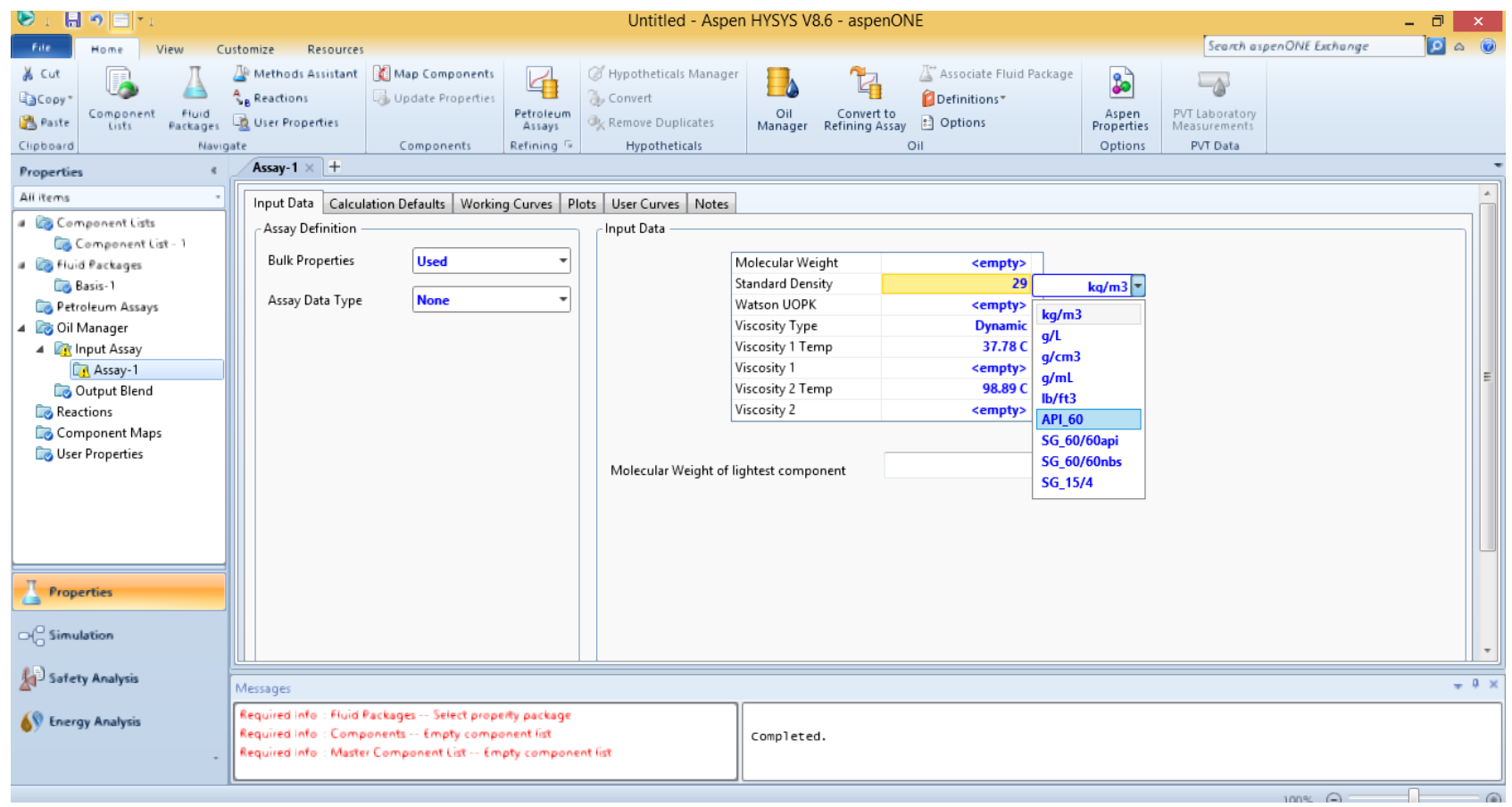

Figure 1. Crude characterization using oil manager tool.

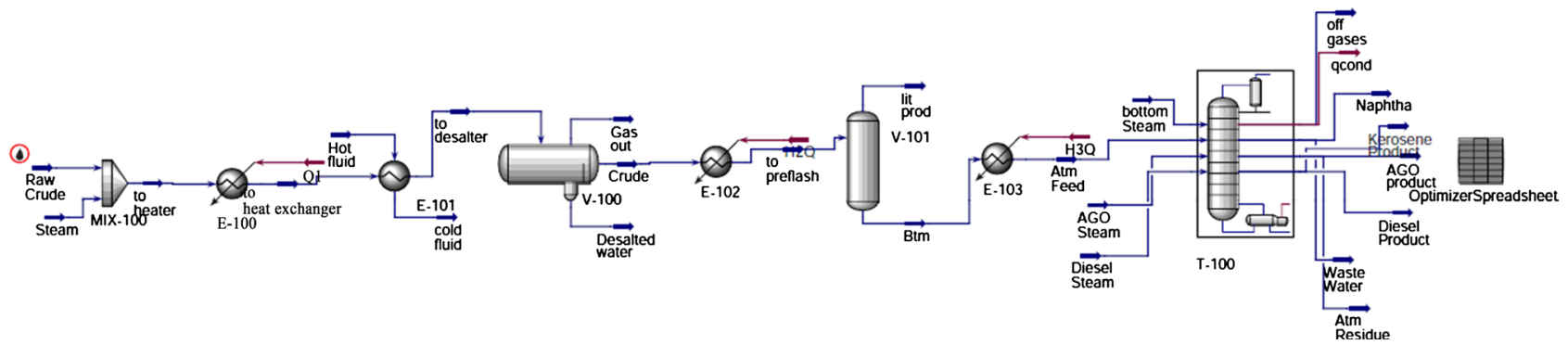

Figure 2. Construction of the crude model into Aspen HYSYS.

programming (SQP) which is shown in Figure 3 and Figure 4 respectively.

\section{Results and Discussion}

\subsection{Characterization Result}

The characterization of the crude assay was able to predict and generate True Boiling Point (TBP) curve which is shown in Figure 5. The result was also able to predict the mole percent that will be distilled at a corresponding temperature. At $100^{\circ} \mathrm{C} 20$ mole percent has been distilled, at $400^{\circ} \mathrm{C} 60$ mole percent has been distilled, at $600^{\circ} \mathrm{C} 90$ mole percent has been distilled and finally at $800^{\circ} \mathrm{C} 99$ mole percent has been distilled. The red line indicates the calculated or predicted values while the green line indicates the inputted values.

\subsection{Model Result}

Table 1 shows the comparison between the model prediction and plant data in terms of composition as well as the percent deviation. 


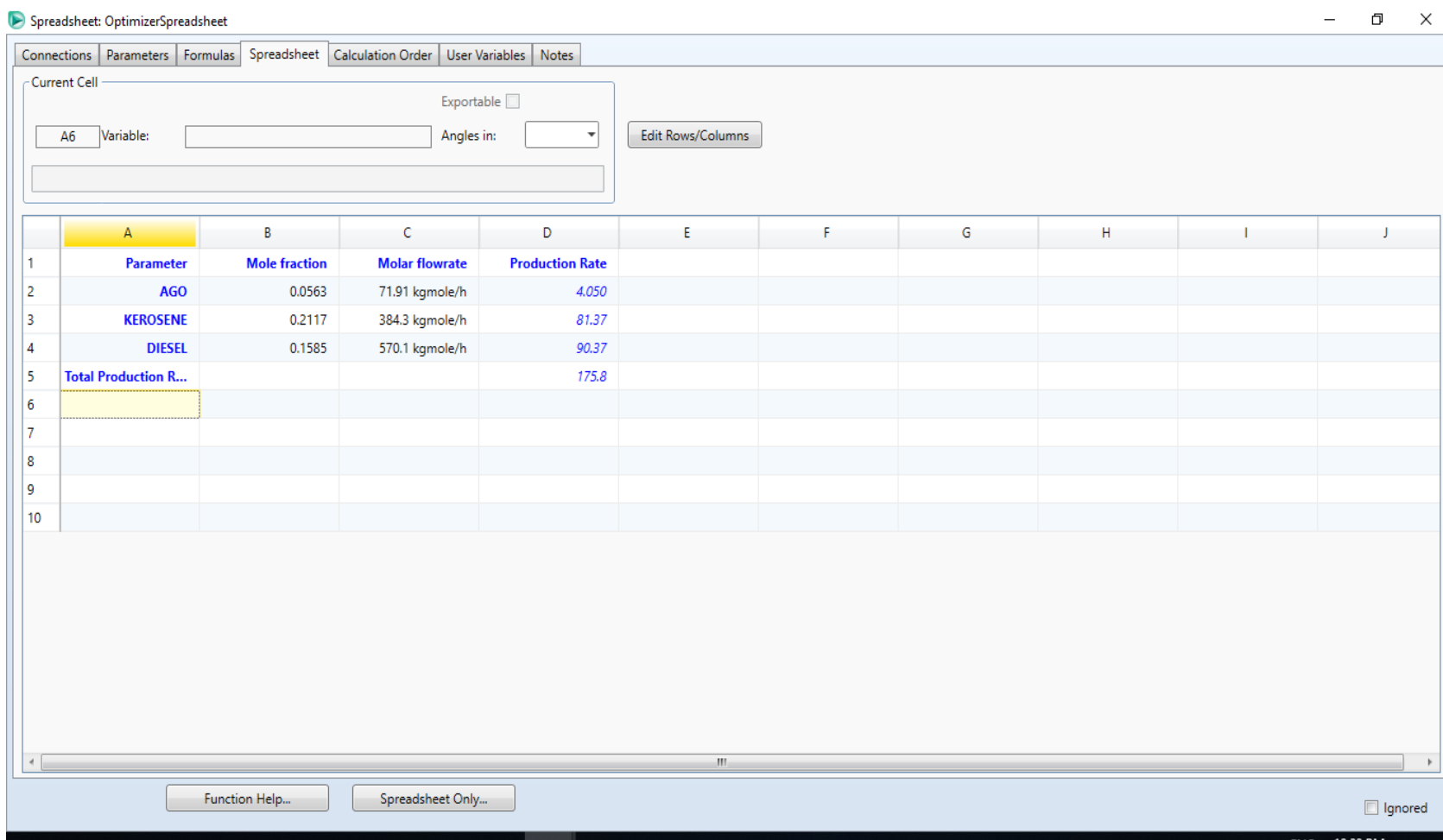

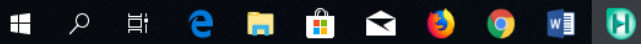

Figure 3. Building the spreadsheet for the optimization.

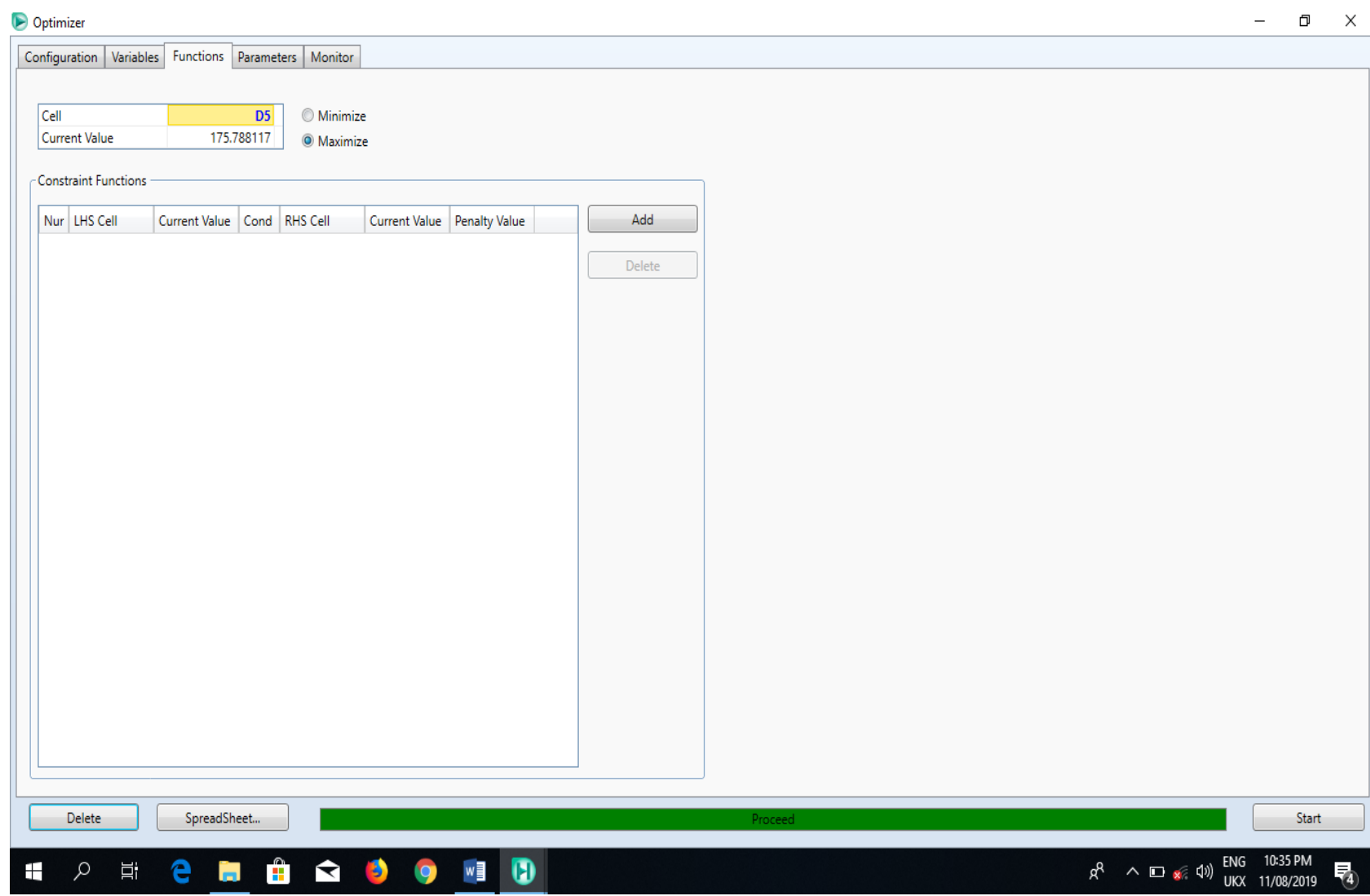

Figure 4. Optimizing the objective function. 


\section{TBP Distillation - Blend-1}

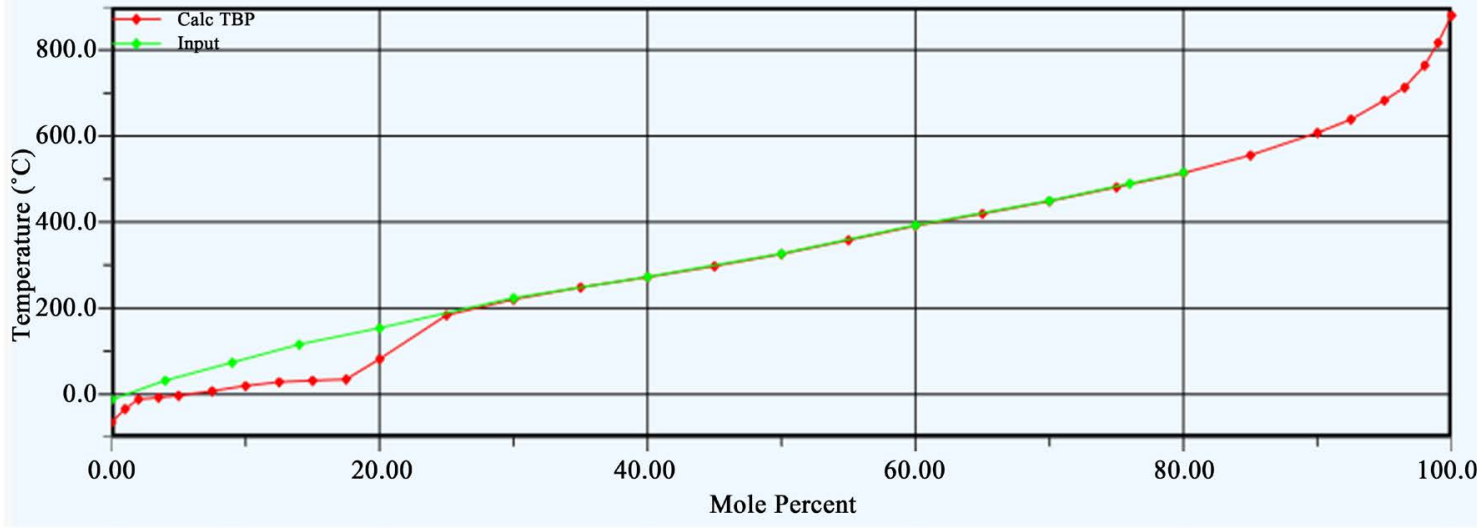

Figure 5. True boiling point assay curve.

Table 1. Comparison between model prediction and plant data in terms of composition.

\begin{tabular}{ccccc}
\hline \multirow{2}{*}{ Tray No } & \multicolumn{4}{c}{ Composition } \\
\cline { 2 - 5 } & Component & Plant Data & Model & \% Deviation \\
\hline 1 & Naphtha & 0.271 & 0.2677 & 1.22 \\
12 & Kerosene & 0.156 & 0.1572 & 0.76 \\
25 & LDO & 0.265 & 0.2687 & 1.40 \\
35 & HDO & 0.053 & 0.0547 & 3.21 \\
48 & Atm Residue & 0.255 & 0.2517 & 1.30 \\
\hline
\end{tabular}

Table 2. Comparison between model and plant data in terms of temperature.

\begin{tabular}{ccccc}
\hline \multirow{2}{*}{ Tray No } & \multicolumn{4}{c}{ Temperature } \\
\cline { 2 - 5 } & Component & Plant Data & Model & \% Deviation \\
\hline 1 & Naphtha & 150 & 120 & 20 \\
12 & Kerosene & 210 & 206 & 1.9 \\
25 & LDO & 280 & 215 & 23.2 \\
35 & HDO & 310 & 310 & 0.0 \\
48 & Atm Residue & 320 & 320 & 0.0 \\
\hline
\end{tabular}

Table 2 shows the comparison between the model prediction and plant data in terms of Temperature as well as the percent deviation.

\subsection{Optimization Result}

Table 3 shows the summary of the optimization result in terms of composition (mole Fraction) for the five products shown above.

Table 4 shows the summary of the optimization result in terms of Temperature for the five products shown above.

Table 5 shows the summary of comparison between base case and optimized case for naphtha product in terms of the functional parameters listed above. 
Table 6 shows the summary of comparison between base case and optimized case for kerosene product in terms of the functional parameters listed above.

Table 3. Summary of optimized results in terms of composition.

\begin{tabular}{ccc}
\hline Tray No & Component & Composition (Mole Fraction) \\
\hline 1 & Naphtha & 0.2713 \\
12 & Kerosene & 0.1540 \\
25 & LDO & 0.2635 \\
35 & HDO & 0.0628 \\
48 & Atm Residue & 0.2584 \\
\hline
\end{tabular}

Table 4. Summary of optimized results in terms of temperature.

\begin{tabular}{ccc}
\hline S/N & Component Withdrawn & Temperature $\left({ }^{\circ} \mathrm{C}\right)$ \\
\hline 1 & Naphtha & 129 \\
2 & Kerosene & 221 \\
3 & LDO & 257 \\
4 & HDO & 317 \\
5 & Atm Residue & 327 \\
\hline
\end{tabular}

Table 5. Summary of comparison between base case and optimized case for naphtha product.

\begin{tabular}{cccc}
\hline Parameters & Base Case & Optimized Case & Difference \\
\hline Vapour fraction & 0.0000 & 0.000 & 0.0000 \\
Temperature & 51.29 & 58.79 & 7.5 \\
Pressure & 140.0 & 140.0 & 0.00 \\
Molar flow & 879.4 & 850.5 & 28.9 \\
Mass flow & $7.512 \mathrm{e}+004$ & $7.656 \mathrm{e}+004$ & $0.144 \mathrm{e}+004$ \\
Liquid volume & 104.3 & 104.3 & 0.00 \\
Heat flow & $-1.662 \mathrm{e}+008$ & $-1.670 \mathrm{e}+008$ & $0.008 \mathrm{e}+008$
\end{tabular}

Table 6. Summary of comparison between base case and optimized case for kerosene product.

\begin{tabular}{cccc}
\hline Parameters & Base Case & Optimized Case & Difference \\
\hline Vapour fraction & 0.0000 & 0.0000 & 0.0000 \\
Temperature & 205.9 & 221.0 & 15.1 \\
Pressure & 207.0 & 207.0 & 0.00 \\
Molar flow & 384.3 & 364.0 & 20.3 \\
Mass flow & $5.183 \mathrm{e}+004$ & $5.239 \mathrm{e}+004$ & 560 \\
Liquid volume & 64.10 & 64.10 & 0.00 \\
Heat flow & $-1.518 \mathrm{e}+007$ & $-9.678 \mathrm{e}+007$ & $8.16 \mathrm{e}+007$ \\
\hline
\end{tabular}


Table 7 shows the summary of comparison between base case and optimized case for Light Diesel Oil (LDO) product in terms of the functional parameters listed above.

Table 8 shows the summary of comparison between base case and optimized case for Heavy Diesel Oil (HDO) product in terms of the functional parameters listed above.

Table 9 shows the summary of comparison between base case and optimized case for atmospheric residue product in terms of the functional parameters listed above.

Table 7. Summary of comparison between base case and optimized case for LDO product.

\begin{tabular}{cccc}
\hline Parameters & Base Case & Optimized Case & Difference \\
\hline Vapour fraction & 0.0000 & 0.0000 & 0.0000 \\
Temperature & 247.5 & 257.7 & 10.2 \\
Pressure & 215.3 & 215.3 & 0.00 \\
Molar flow & 570.1 & 549.0 & 21.1 \\
Mass flow & $1.105 \mathrm{e}+005$ & $1.112 \mathrm{e}+005$ & $0.007 \mathrm{e}+005$ \\
Liquid volume & 128.9 & 128.9 & 0.00 \\
Heat flow & $-1.837 \mathrm{e}+008$ & $-1.817 \mathrm{e}+008$ & $0.02 \mathrm{e}+008$ \\
\hline
\end{tabular}

Table 8. Summary of comparison between base case and optimized case for HDO product.

\begin{tabular}{cccc}
\hline Parameters & Base Case & Optimized Case & Difference \\
\hline Vapour fraction & 0.0000 & 0.0000 & 0.0000 \\
Temperature & 309.8 & 317.3 & 7.5 \\
Pressure & 230.0 & 230.0 & 0.00 \\
Molar flow & 71.91 & 70.59 & 1.32 \\
Mass flow & $2.969 \mathrm{e}+004$ & $2.977 \mathrm{e}+004$ & $0.008 \mathrm{e}+004$ \\
Liquid volume & 30.69 & 30.69 & 30.69 \\
Heat flow & $-4.466 \mathrm{e}+007$ & $-4.417 \mathrm{e}+007$ & $0.049 \mathrm{e}+007$ \\
\hline
\end{tabular}

Table 9. Summary of comparison between base case and optimized case for atmospheric residue product

\begin{tabular}{cccc}
\hline Parameters & Base Case & Optimized Case & Difference \\
\hline Vapour fraction & 0.0000 & 0.0000 & 0.0000 \\
Temperature & 320.3 & 327.7 & 0.0000 \\
Pressure & 230.0 & 230.0 & 0.000 \\
Molar flow & 793.7 & 793.7 & 0.000 \\
Mass flow & $3.157 \mathrm{e}+005$ & $3.157 \mathrm{e}+005$ & 0.000 \\
Liquid volume & 328.1 & 328.1 & 0.000 \\
Heat flow & $-4.651 \mathrm{e}+008$ & $-4.651 \mathrm{e}+008$ & 0.000 \\
\hline
\end{tabular}




\section{Effect of Temperature on Tray Position}

Figure 6 shows that the temperature is increasing with tray position. The model also predicted the tray of withdrawal corresponding to temperature of the product to be withdrawn. The temperature of the column rises from $120^{\circ} \mathrm{C}$ to $320^{\circ} \mathrm{C}$ before falling to $320^{\circ} \mathrm{C}$. The reason for this is because more and more product are withdrawn from the column i.e. more cooler liquid falls down the column against the rising gas leaving at the top, therefore a reboiler is needed to add more heat via steam or hot oil as a result of this temperature drop in order to balance the temperature of the column. Because at the bottom we want the heavy components to remain as liquid and lighter components as gas since most liquid products are withdrawn at the bottom.

\section{Effect of Pressure on Tray Position}

Figure 7 shows the pressure distribution along the trays of the column. The model also predicted that the pressure in the trays is increasing from the first to the last tray since the total peruse is operated at atmospheric pressure, it is expected that the pressure at the bottom of the column is greater than the pressure at the top, hence this validates the model.

\section{Effect of mole Fraction Ratio on Tray Position}

The mole fraction ratio of the total products is depicted by the graph in Figure 8 where the mole fraction of each product is known the tray of withdrawal can be known from the model predicted by Figure 8 .

\section{Effect of Density and Molecular Weight}

In Figure 9, the density and molecular weight of the feed continue to increase and decrease as more products are withdrawn and reflux back to the column. The model also predicted that the density and molecular weight of the feed at the bottom is greater than that at the top, hence this is expected as heavier products settle at the bottom while light products at the top.

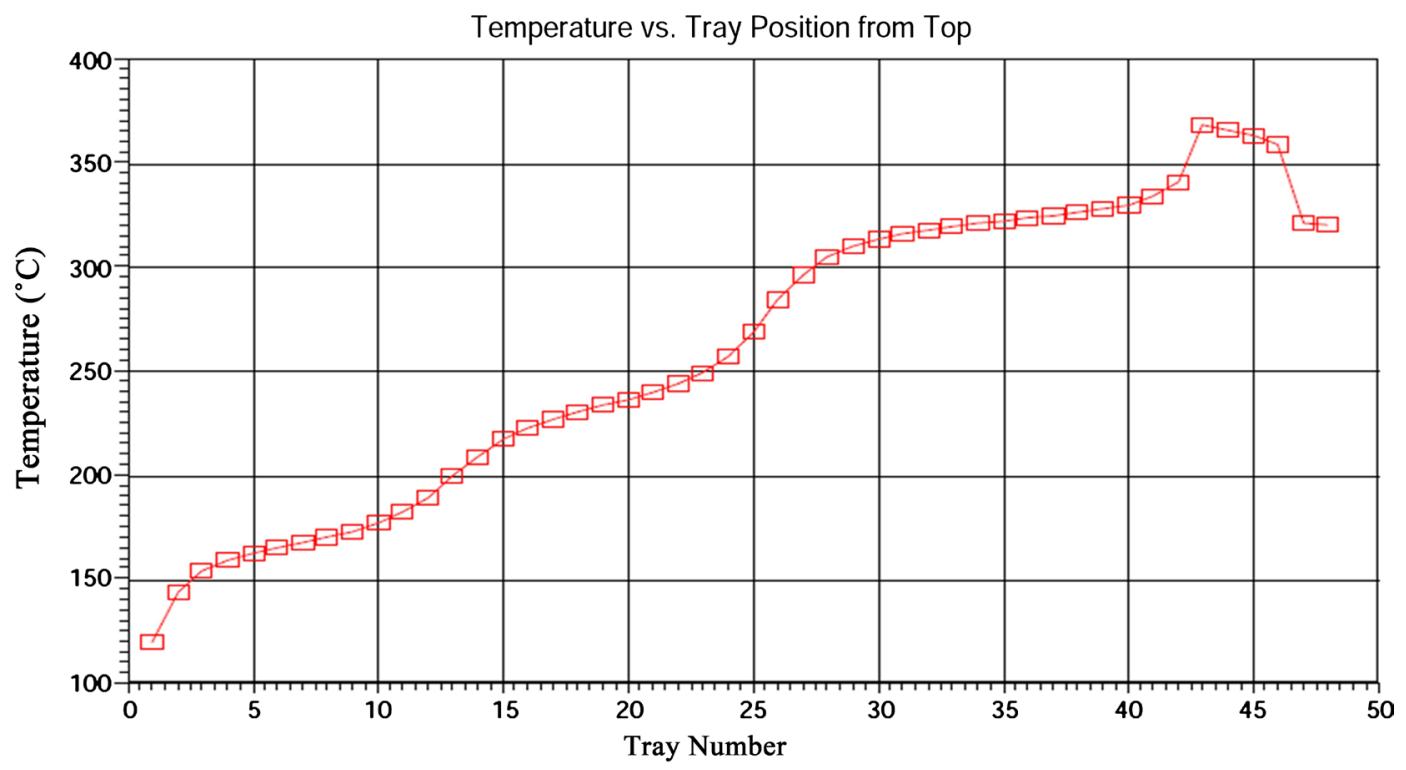

Figure 6. Temperature versus tray position. 


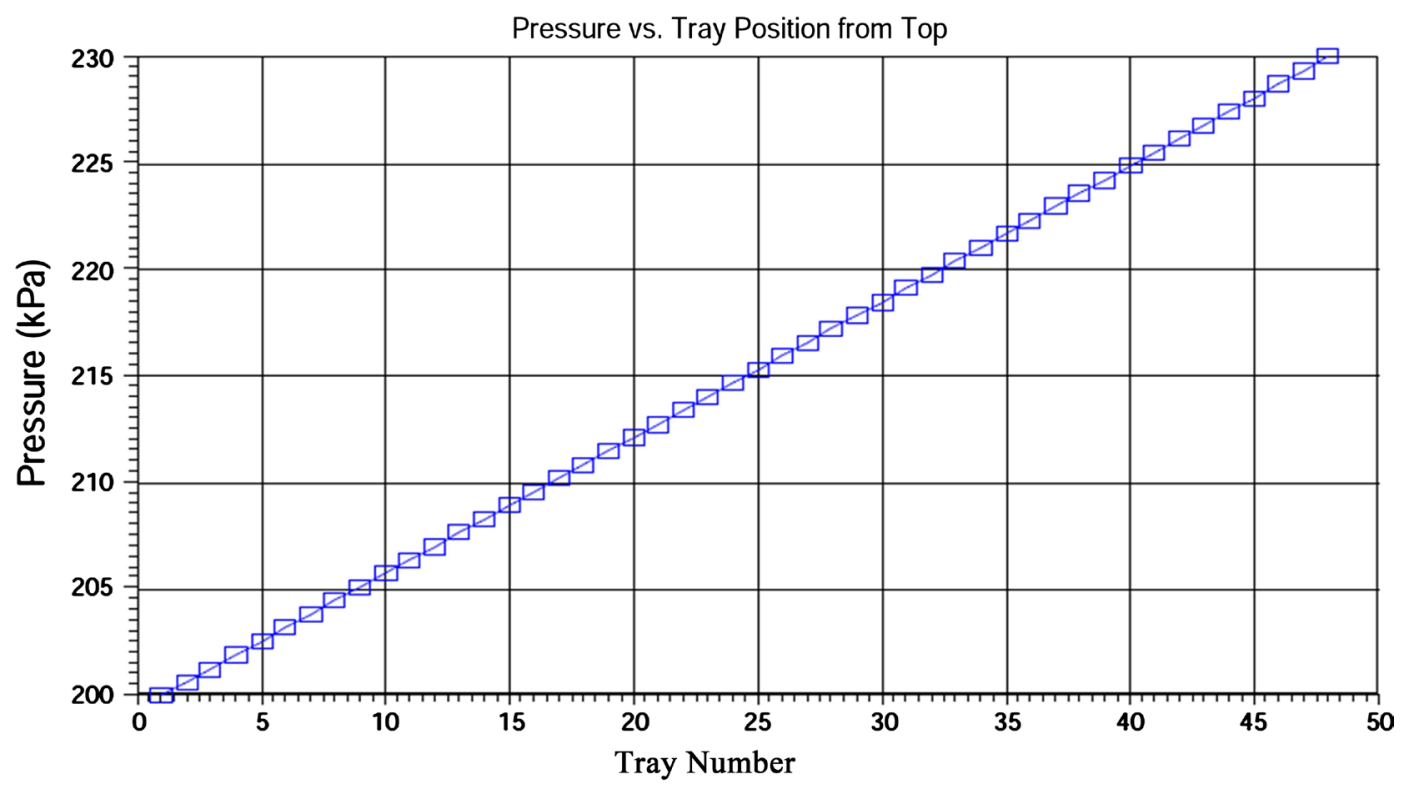

Figure 7. Pressure versus tray position.

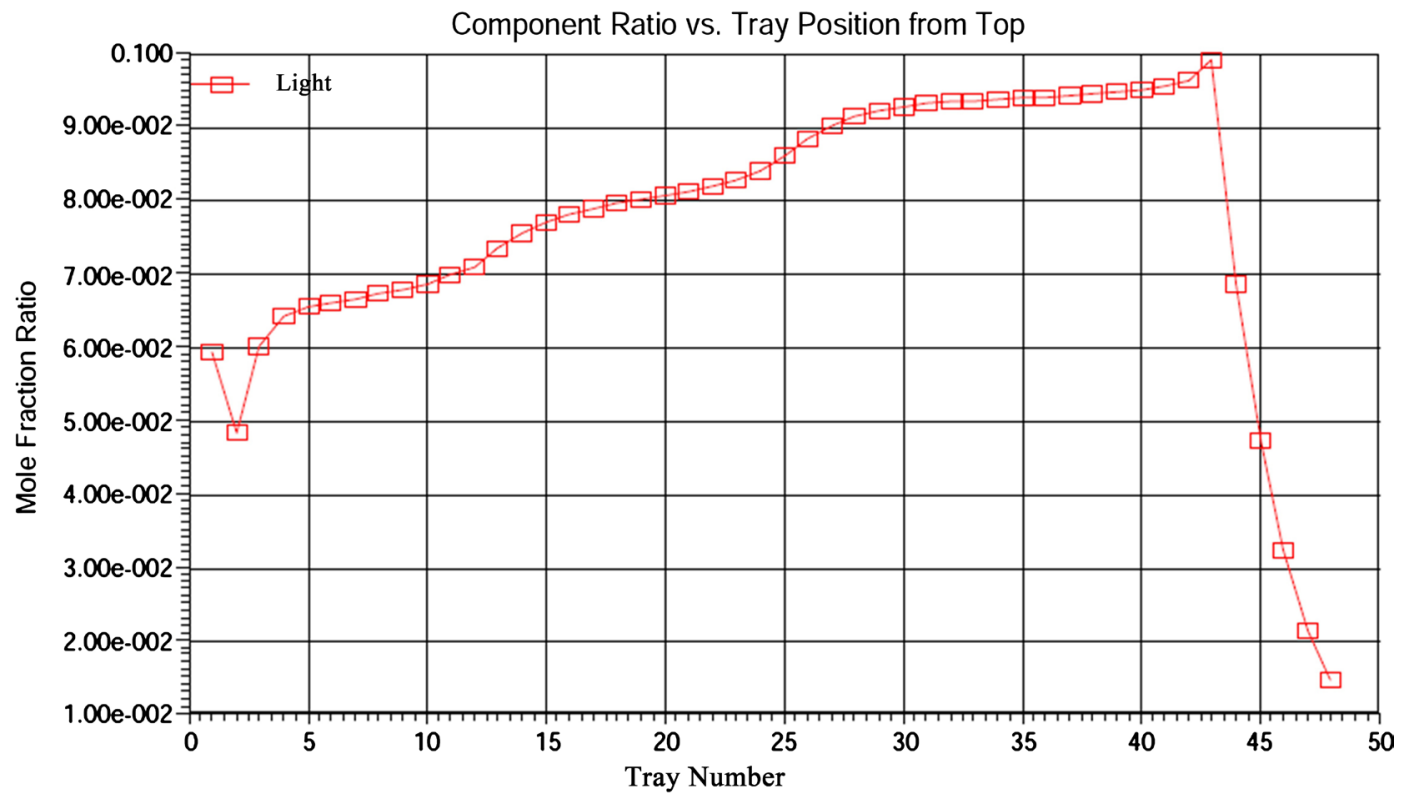

Figure 8. Mole fraction versus tray position.

\section{Conclusions}

A simulation model of a crude distillation unit was developed using aspen HYSYS version 8.8 using data from the Port Harcourt Refining Company. The HYSYS model developed included 1 mixer, 3 heaters, 1 heat exchanger, 1 desalter, a 2-phase separator and the main fractionating column which was modeled as a refluxed absorber in Aspen HYSYS. Optimization of the simulated model was done using sequential quadratic programming (SQP) which is inbuilt in the Aspen HYSYS process simulator. The model results have been able to predict the mole fractions naphtha, kerosene, LDO, HDO and Atm residue as well as the 


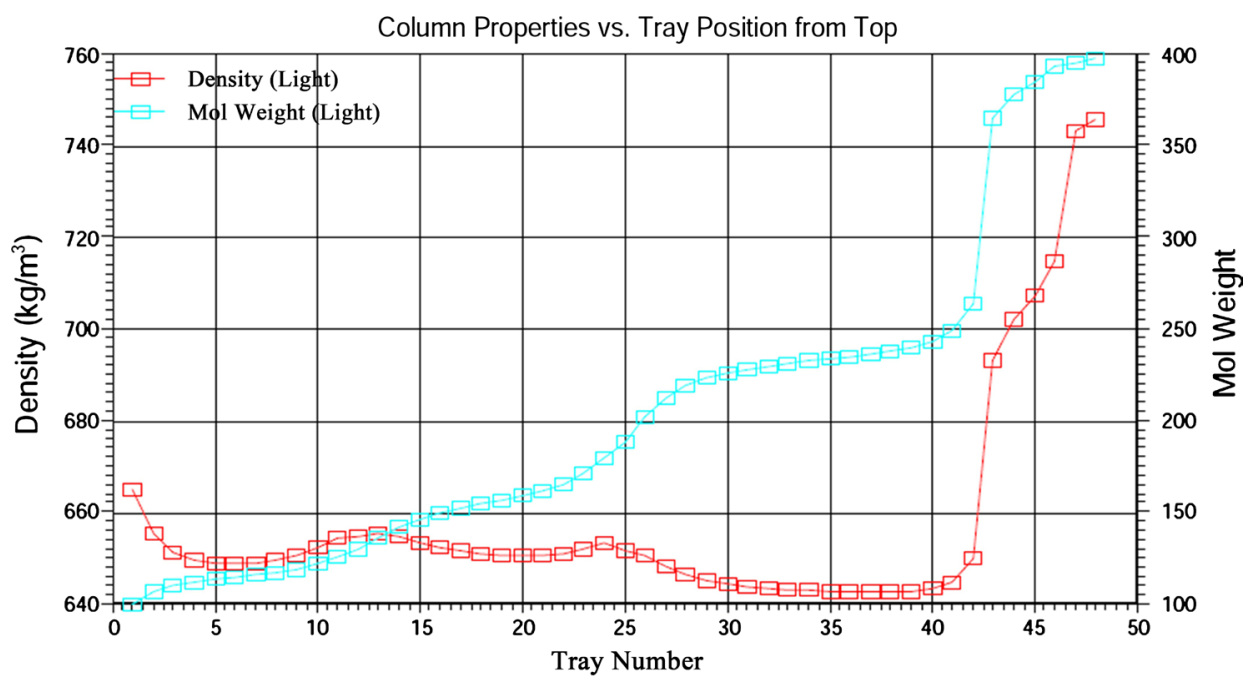

Figure 9. Density versus tray position.

temperature of withdrawal on the trays. Comparison between the simulated and optimized model shows a great improvement in the operating variables such as temperature, mass flow, molar flow, liquid volume flow, and heat flow.

The results of the model predicted the separation of crude oil into naphtha, kerosene, diesel, atmospheric gas oil and atmospheric residue. The model was also able to predict the variation of temperature, density, molar flow, mole fraction, volume flow etc. along the trays. Sequential quadratic programming was used as the optimization method because of its ability to handle both constrained and unconstrained optimization as well as equality and inequality constrained.

\section{Conflicts of Interest}

The authors declare no conflicts of interest regarding the publication of this paper.

\section{References}

[1] Coulson, J. and Richardson, F. (2013) Particle Technology and Separation Processes: Chemical Engineering Volume II. 5th Edition. Elsevier, New Delhi.

[2] Mohammed, J., Aloko, D.F. and Auta, M. (2012) Simulation of Kaduna Refining and Petrochemical Company (KRPC) Crude Distillation Unit (CDU1) Using HYSYS. International Journal of Advanced Scientific Research and Technology, 1, 1-6.

[3] Zhao, H., Rong, G., Feng, Y.P. and Dong, X.Y. (2014) Integration Optimization of Production and Utilizing Systems for Refinery Wide Planning. IFAC Papers online, 24, 959-964.

[4] Liebman, K. and Dhole, V.R. (2003) Integrated Crude Distillation Unit Design. Computer \& Chemical Engineering Journal, 24, 1843-1849.

[5] Akpa, J.G. and Umuze, O.D. (2013) Simulation of a Multi-Component Crude Distillation Column. American Journal of Scientific and Industrial Research, 4, 366-377.

[6] Wang, J.S., Rong, G. and Feng, Y.P. (2009) Optimization Crude Oil Operations with 
Uncertainty, IFAC Papers Online, 3, 1020-1025.

https://doi.org/10.3182/20090603-3-RU-2001.0061

[7] Samborskaya, M.A., Gryaznova, I.A. and Vof, A.V. (2015) Pre-Design Optimization of Crude Oil Distillation Flowsheet. Procedia Chemistry, 15, 134-142. https://doi.org/10.1016/j.proche.2015.10.022

[8] Amit, P. and Tukaram, S. (2013) Integrated Product Blending Optimization for Oil Refinery Operations. IFAC Papers Online, 18, 343-348.

https://doi.org/10.3182/20131218-3-IN-2045.00072 